\title{
Pengaruh Model Pembelajaran Make A Match Berbasis Penilaian Portofolio Terhadap Hasil Belajar IPA
}

\author{
Km. Evita Wulandari ${ }^{1 *}$, Kt. Suarni ${ }^{2}$, Ndara Tanggu Renda ${ }^{3}$ \\ 1,2,3 Jurusan Pendidikan Guru Sekolah Dasar, Singaraja, Indonesia
}

\author{
A R T I C L E I N F O \\ Article history: \\ Received 20 May 2018 \\ Received in revised form \\ 26 June 2018 \\ Accepted 12 July 2018 \\ Available online 22 August \\ 2018 \\ Kata Kunci: \\ make a match, penilaian \\ portofolio, hasil belajar IPA \\ Keywords: \\ make a match, assessment \\ portofolio, science learning \\ outcomes
}

\begin{abstract}
A B S T R A K
Penelitian ini dilakukan berdasarkan pada permasalahan rendahnya hasil belajar ipa dan kurangnya pemanfaatan model pembelajaran yang inovatif. Penelitian ini bertujuan untuk mengetahui pengaruh yang signifikan model pembelajaran Make a Match berbasis penilaian portofolio terhadap hasil belajar siswa kelas V di SD Gugus VIII Kecamatan Sawan, Kabupaten Buleleng Tahun Pelajaran 2017/2018. Jenis penelitian ini adalah penelitian kuasi eksperimen dengan rancangan non equivalent post-test only control group design. Populasi penelitian ini adalah siswa kelas V SD di Gugus VIII Kecamatan Sawan Kabupaten Buleleng Tahun pelajaran 2017/2018 yang berjumlah 120 siswa. Sampel penelitian adalah siswa kelas V SD Negeri 1 Sudaji dan siswa kelas V SD Negeri 2 Sudaji. Data hasil belajar IPA dikumpulkan dengan intrumen tes pilihan ganda. Teknik analisis yang digunakan adalah analisis statistik deskriptif dan statistik inferensial Uji-t. Berdasarkan hasil analisi data, diperoleh $t_{\text {hitung }}=4,349$ dan $t_{\text {tabel }}$ (pada taraf signifikan $5 \%$ ) $=2,011$. Ini beararti model pembelajaran Make A Match berbasis penilaian portofolio berpengaruh terhadap hasil belajar IPA siswa SD kelas V di Gugus VIII Kecamatan Sawan Kabupaten Buleleng Tahun Pelajaran 2017/2018.
\end{abstract}

\section{A B S T R A C T}

This research is based on the problem about low learning result in science subject and the lack utilization of innovative learning model. The purpose of this research is to know the difference of science learning result between the students who learned with Make a match model based on portfolio assessment and conventional model. The type of this study was quasi experimental research with non-equivalent design post-test only control group design. Populations of the study are $1205^{\text {th }}$ grade students in SD Gugus VIII, Kecamatan Sawan, Kabupaten Buleleng in the School Year of 2017/2018. The samples of the study are the $5^{\text {th }}$ grade students of SD Negeri 1 Sudaji and the $5^{\text {th }}$ grade students of SD Negeri 2 Sudaji. The data were collected by using a multiple choice instrument and analyzed using descriptive statistical analysis and t-test inferential statistic. The result showed that $t$ count $=$ 4,349 and t table (at 5\% significant level) $=2,011$. It means that the Make a Match learning model based on portfolio assessment affects learning result of science subject of $5^{\text {th }}$ grade students in SD Gugus VIII, Kecamatan Sawan, Kabupaten Buleleng, School Year of 2017/2018. 


\section{Pendahuluan}

Pendidikan merupakan kebutuhan hidup manusia mutlak yang harus dipenuhi demi tercapainya tujuan hidup. Tanpa pendidikan mustahil suatu kelompok manusia dapat hidup berkembang sejalan aspirasi (cita cita). untuk maju, sejahtera, dan bahagia. Kesadaran pentingnya pendidikan yang dapat memberikan harapan dan kemungkinan yang lebih baik di masa mendatang, telah mendorong berbagai upaya dan perhatian seluruh lapisan masyarakat terhadap setiap gerak langkah dan perkembangan dunia pendidikan. Untuk itu diatur dalam Undang-Undang No. 20 tahun 2003 tentang Sistem Pendidikan Nasiomal, dimana dalam undang-undang untuk mencapai tujuan pendidikan nasional maka ditempuh melalui pendidikan formal, informal dan non formal. Khususnya dalam pendidikan formal dapat dilakukan melalui pemberian mata pembelajaran-mata pelajaran sebagaimana diatur dalam pasal 37 ayat 1 yang menyebutkan bahwa kurikulum pada jenjang pendidikan dasar dan menengah wajib memuat 10 mata pelajaran. Salah satunya yaitu mata pelajaran Ilmu Pengetahuan Alam (IPA)

IPA merupakan salah satu mata pelajaran pokok yang terdapat dalam kurikulum di Indonesia dan selalu diberikan pada setiap jenjang pendidikan sehingga IPA perlu dikembangkan dalam setiap proses pembelajarannya. Hal ini sesuai dengan penjelasan Kardi dan Nur (dalam Trianto, 2010) bahwa pembelajaran IPA pada tingkat manapun harus dikembangkan. Berdasarkan Permendiknas No. 22 tahun 2006 menyatakan bahwa "IPA berkaitan dengan cara mencari tahu tentang alam secara sistematis sehingga IPA bukan hanya penguasaan kumpulan pengetahuan yang berupa fakta-fakta, konsep-konsep, atau prinsip-prinsip saja tetapi juga merupakan suatu proses penemuan". Sejalan dengan pendapat (Usman Samatowa, 2010:3) menyatakan bahawa ilmu pengetahuan alam merupakan terjemahan katakata dalan bahasa inggris yaitu natural science, artinya ilmu pengetahuan alam (IPA). Berhubungan dengan alam atau bersangkut paut dengan alam, sience artinya ilmu pengetahuan. Jadi ilmu pengetahuan alam (IPA) atau science mempelajari peristiwa-peristiwa yang terjadi di alam ini.

Pendidikan IPA diharapkan dapat menjadi wahana bagi peserta didik untuk mempelajari diri sendiri dan alam sekitar, serta prospek pengembangan lebih lanjut dalam menerapkannya di dalam kehidupan sehari-hari. Tujuan pembelajaran IPA di sekolah dasar dalam badan nasional standar pendidikan (BNSP) salah satunya mengembangkan pengetahuan dan pemahaman konsep-konsep IPA yang bermanfaat dan dapat diterapkan dalam kehidupan sehari-hari. Untuk mencapai tujuan tersebut pembelajaran IPA harus sesuai dengan karakteristik siswanya yang masih berada pada tahap oprasional konkret, yang belum bisa berfikir abstrak dan memiliki karakteristik yang beragam seperti senang bermain, suka meniru, bekerja dalam kelompok, dan senantiasa ingin melaksanakan atau merasakan sendiri Piaget (dalam Susanto, 2013). Mata pelajaran IPA merupakan salah satu mata pelajaran yang memiliki cakupan materi yang cukup luas dan padat. Sehingga kemampuan guru dalam menyajikan materi pada mata pelajaran IPA harus dipersiapkan dengan baik. Apabila guru kurang mampu menyajikan materi tersebut dengan baik dan menarik, maka dapat mengakibatkan siswa menjadi bosan dan jenuh (Mulyantini, 2017). Oleh sebab itu, pembelajaran IPA di SD hendaknya dirancang agar sesuai dengan kebutuhan siswanya. Sehingga dapat meningkatkan hasil belajar siswa pada mata pelajaran IPA pada khususnya.

Berdasarkan hasil wawancara dengan guru yang mengajar mata pelajaran IPA di kelas V SD pada tanggal 9-10 November 2017 di Gugus VIII Kecamatan Sawan diperoleh informasi yaitu (1) siswa pasif atau lebih banyak diam saat pelaksanaan pembelajaran; (2) cenderung siswa bosan atau tidak senang pada mata pelajaran IPA; (3) hasil belajar cenderung rendah dibuktikan dengan hasil UAS siswa kelas V di gugus VIII Kecamatan Sawan, Kabupaten Buleleng

Selanjuntnya pelaksanaan observasi yang telah dilakukan di SD Gugus VIII Kecamatan Sawan yaitu SD 1 Sudaji, SD 2 Sudaji, SD 3 Sudaji, SD 4 Sudaji, SD 5 Sudaji, SD 6 Sudaji pada tanggal 25-26 November 2017 yaitu dengan mengobservasi guru saat melaksanakan pembelajaran IPA di kelas mendapatkan hasil yaitu : (1) pembelajaran yang dilaksanakan dikelas lebih banyak menggunakan metode ceramah; (2) Penialain yang digunakan guru masih konvensional tanpa melihat perkembanagn setiap pelaksaan pembelajaran; (3) siswa pasif dan hanya diam saat pelaksanaan pembelajaran berlangsung

Kondisi di atas diperkuat dengan hasil pencatatan dokumen yang dilakukan di seluruh SD Gugus VIII Kecamatan Sawan. Berdasarkan studi dokumen pada pembelajaran IPA, maka didapatkan rata-rata nilai UAS mata pelajaran IPA yang dimiliki setiap SD di Gugus VIII Kecamatan Sawan yang masih di bawah rata-rata KKM. Diketahui rata-rata hasil tes IPA di SDN 1 Sudaji adalah, 60,95, SDN 2 Sudaji adalah 65,95, SDN 3 Sudaji adalah 62,88, SDN 4 Sudaji adalah 60,31, SDN 5 Sudaji adalah 64,93 dan SDN 6 Sudaji adalah 60,92 .

Berdasarkan nilai rata-rata UAS IPA siswa kelas V di SD Gugus VIII Kecamatan Sawan berkisar antara 60,31 sampai dengan 64,93 jika dikonversikan terhadap Penilaian Acuan Patokan (PAP) (dalam Agung, 2014:118) berada pada kategori cukup. Dengan demikian dapat diklasifikasikan bahwa nilai rata- 
rata UAS IPA siswa kelas V gugus VIII Kecamatan Sawan dikatakan cukup. Hal ini merupakan suatu masalah yang harus diatasi agar hasil belajar ssiwa menjadi lebih baik. Maka dari itu perlu sebuah inovasi pembelajaran untuk meningkatkan hasil belajar IPA. Inovasi pembelajaran yang tepat untuk mengatasi masalah di atas perlu diterapkan berbagai jenis pendekatan, strategi, dan model pembelajaran

Berdasarkan permasalahan di atas, salah satu solusi yang dapat ditawarkan adalah menggunakan model pembelajaran Make a Match, karena model ini menekankan siswa untuk berkerjasama antar siswa lain dan mengmbangkan pengetahuan melalui belajar sambil bermain. Menurut Shoimin (2014) "teknik ini bisa digunakan dalam semua mata pelajaran dan untuk semua tingkat". Model pembelajaran make a match sangat efektif mambantu siswa dalam memahami materi melalui permainan mencari kartu jawaban atau pertanyaan, sehingga dapat meciptakan proses pembelajaran yang menyenangkan bagi siswa. Sejalan dengan hal tersebut menurut Yesiana (2016) Model pembelajaran make a match adalah "sistem pembelajaran yang mengutamakan penanaman kemampuan social terutama kemampuan bekerja sama, kemampuan berinteraksi disamping kemampuan berpikir cepat melalui permainan mencari pasangan dengan dibantu kartu" Pembelajaran make a match akan tercapai dan sesuai dengan tujuan yang diharapkan, jika beberapa tahap persiapan ini sudah dilakukan antara sebagai berikut: (1) Guru menyiapkan beberapa konsep/topik yang cocok untuk sesi review satu sisi kartu soal dan satu sisi berupa kartu jawaban beserta gambar. (2) Setiap peserta didik mendapat satu kartu dan memikirkan. (3) Peserta didik mencari pasangan yang mempunyai kartu yang cocok dengan kartunya (kartu soal/kartu jawaban), peserta didik yang dapat mencocokkan kartunya sebelum batas waktu diberi point. (4) Setelah itu babak dicocokkan lagi agar tiap peserta didik mendapat kartu yang berbeda dari sebelumnya. Jika dipadukan dengan penilaian portofolio, maka penggunaan model pembelajaran make a match berbasis penilain portofolio mampu meningkatkan hasil belajar IPA siswa kelas V SD di Gugus VIII, karena Penilaian portofolio merupakan penilaian berbasis kelas terhadap sekumpulan karya peserta didik yang tersusun secara sistematis dan terorganisasi yang diambil selama proses pembelajaran dalam kurun waktu tertentu

Berdasarkan uraian dia atas, maka penelitian ini akan difokuskan pada Pengaruh Model Pembelajaran Make a Match Berbasis Penilaian Portofolio Terhadap hasil Belajar IPA Siswa Kelas V SD Semester Genap di Gugus VIII Kecamatan Sawan, Kabupaten Buleleng Tahun Pelajaran 2017/2018.

\section{Metode}

Jenis penelitian ini adalah kuasi eksperimen. Disebut demikian karena tidak semua variabel yang muncul dapat dikontrol secara ketat. Rancangan kuasi eksperimen yang digunakan adalah non equivalent posttest only control group design. Penelitian melibatkan kelompok kontrol sebagai pembanding kelompok eksperimen.Populasi penelitian ini adalah siswa kelas V SD di Gugus VIII Kecamatan Sawan Kabupaten Buleleng Tahun Pelajaran 2017/2018 yang berjumlah 121 siswa. Banyaknya populasi dan sebaran dapat dilihat pada Tabel 1. Berikut.

Tabel 1. Populasi Penelitian

\begin{tabular}{lcc}
\hline & SD di Gugus VIII & \\
No. & Kecamatan Sawan & 23 \\
\hline 1. & SD Negeri 1 Sudaji & 26 \\
2. & SD Negeri 2 Sudaji & 23 \\
3. & SD Negeri 3 Sudaji & 19 \\
4. & SD Negeri 4 Sudaji & 15 \\
5. & SD Negeri 5 Sudaji & 14 \\
6. & SD Negeri 6 Sudaji & 120
\end{tabular}

Sampel ditentukan dengan teknik random sampling pada anggota populasi yang dinyatakan setara. Pengacakan dilakukan dengan undian.Pengundian dilakukan sebanyak dua kali, yaitu (1) menentukan sampel, dan (2) menentukan kelompok eksperimen dan kelompok kontrol. Setelah dilakukan uji kesetaraan dengan Anava satu jalur dan dilakukan pengundian sebanyak dua kali, sampel penelitian ini adalah siswa kelas V SD Negeri 1 Sudaji yang berjumlah 23 orang yang digunakan sebagai kelompok eksperimen dan siswa kelas V SD Negeri 2 Sudaji yang berjumlah 26 orang yang digunakan sebagai 
kelompok kontrol

Variabel yang digunakan pada penelitian ini ada 2 jenis, yaitu variabel bebas dan terikat. Variabel bebas adalah model pembelajaran Make a Match berbasis penilaian portofolio dan model pembelajaran konvensional. Model pembelajaran Make a Match berbasis penilaian portofolio diterapkan pada kelas eksperimen dan model pembelajaran konvensional diterapkan pada kelas kontrol. Masing-masing pembelajaran dilakukan sebanyak 8 kali pertemuan yaitu tujuh kali pembelajaran dan satu kali post-test. Variabel terikat adalah hasil belajar IPA. Hasil belajar IPA diukur melalui post-test

Data yang dikumpulkan dalam penelitian ini adalah data tentang hasil belajar IPA dikumpulkan dengan instrument berupa tes pilihan ganda.Hasil belajar IPA yang diukur adalah pada domain kognitif yang didasarkan pada Taksonomi Bloom revisi Anderson dan Krathwohl meliputi (1) mengingat,(2) memahami, (3) menerapkan, (4) menganalisis, (5) mengevaluasi, dan (6) menciptakan

Uji validitas instrumen hasil belajar IPA meliputi uji validitas isi, uji validitas butir, uji reliabilitas, uji tingkat kesukaran, dan daya beda butir tes. Setelah dilakukan validasi instrumen, dari 40 butir pernyataan pada tes hasil belajar IPA digunakan 30 butir pertanyaan. Data yang telah diperoleh dianalisis menggunakan analisis deskriptif, dan inferensial.Analisis deskriptif yang dilakukan, meliputi menghitung nilai rata-rata (mean), median, modus, standar deviasi, variansi, skor maksimum, dan skor minimum.Data dalam penelitian ini disajikan dalam bentuk grafik polygon. Rata-rata hitung yang diperoleh kemudian dikategorikan berdasarkan skala lima. Analisis inferensial yang dilakukan, meliputi uji prasyarat dan uji hipotesis.uji prasyarat analisis yang dilakukan, meliputi uji normalitas sebaran data dan uji homogenitas varians. Uji normalitas dilakukan untuk mengetahui data berasal dari populasi yang berdistribusi normal atau tidak normal.Uji homogenitas varians dilakukan untuk mengetahui kehomogenan variansi dari data hasil belajar IPA.Uji hipotesis menggunakan analisis uji-t dengan membandingkan 1 variabel bebas dan 1 variabel terikat.Sebelum melakukan uji hipotesis, ada beberapa prasyaratan yang harus dipenuhi dan perlu dibuktikan. Prasyaratan yang dimaksud yaitu: (1) data harus berdistribusi normal, (2) data yang dianalisis bersifat homogen atau tidak. Kedua prasyarat tersebut harus diuji terlebih dahulu dalam uji prasyarat analisis data.Uji prasyarat dilakukan dengan bantuan Microsoft Office Excel 2007.

\section{Hasil dan Pembahasan}

Hasil analisis deskriptif data hasil belajar IPA kelompok eksperimen menunjukkan bahwa skor rata-rata adalah 27,01 kategori sangat tinggi. Pengukuran hasil belajar IPA kelompok kontrol menunjukkan bahwa skor rata-rata adalah 21,50 kategori sedang. Terlihat bahwa skor rata-rata pada kelompok eksperimen lebih besar dari rata-rata skor kelompok kontrol.Hal ini terlihat dari hasil analisis hasil deskriptif data hasil belajar IPA. Rangkuman hasil deskripsi data hasil belajar IPA pada penelitian ini dapat dilihat pada Tabel 2 .

Tabel 2. Analisis Data dengan Statsistik Deskripstif

\begin{tabular}{lccc}
\hline Statistik & \multicolumn{2}{c}{ Kelompok Eksperimen } & Kelompok Kontrol \\
\hline Mean & 23,174 & 17,846 & \\
Median & 24,142 & 17,17 & \\
Modus & 25,750 & & 16,167 \\
Standar Deviasi & 4,285 & 17,835 & 4,223 \\
Varians & 18,360 & \multicolumn{2}{c}{} \\
\hline
\end{tabular}

Berdasarkan hasil analisis deskriptif pada tabel 1, hasil belajar IPA menunjukkan skor rata-rata hasil belajar IPA kelompok eksperimen lebih tinggi dibandingkan dengan skor rata-rata kelompok kontrol. Tinjauan ini didasarkan pada rata-rata skor dan kecenderungan skor hasil belajar IPA yang diperoleh kedua kelompok. Rata-rata skor hasil belajar IPA pada kelompok eksperimen adalah 23,174 berada pada kategori sangat tinggi. Sebaran data kelompok eksperimen merupakan kurva juling negatif. Artinya, sebagian besar skor siswa cenderung tinggi. Gambaran data hasil belajar IPA pada kelompok eksperimen dapat disajikan ke dalam bentuk histogram pada Gambar 1. 


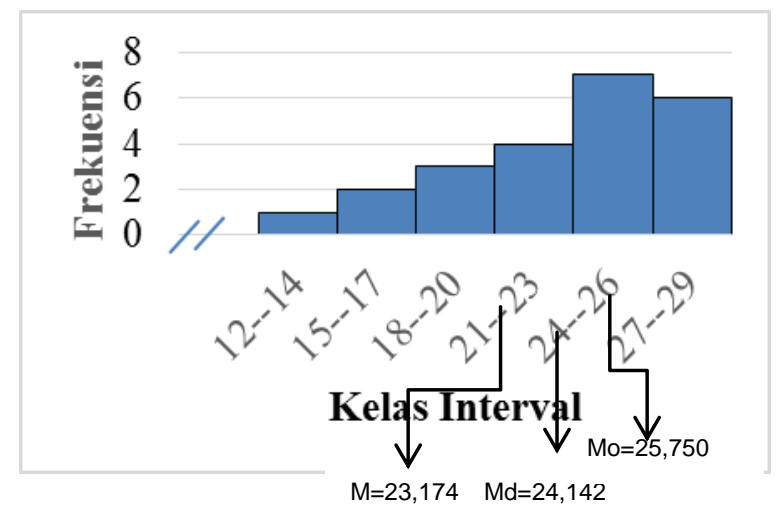

Gambar 1. Histogram Hasil Belajar IPA Kelompok Eksperimen

Pada kelompok kontrol, rata-rata skor hasil belajar IPA pada kelompok kontrol adalah 17,846 berada pada kategori sedang. Sebaran data kelompok kontrol merupakan kurva juling positif. Artinya, sebagian besar skor siswa cenderung rendah. Gambaran data hasil belajar IPA pada kelompok kontrol dapat disajikan ke dalam bentuk histogram pada Gambar 2.

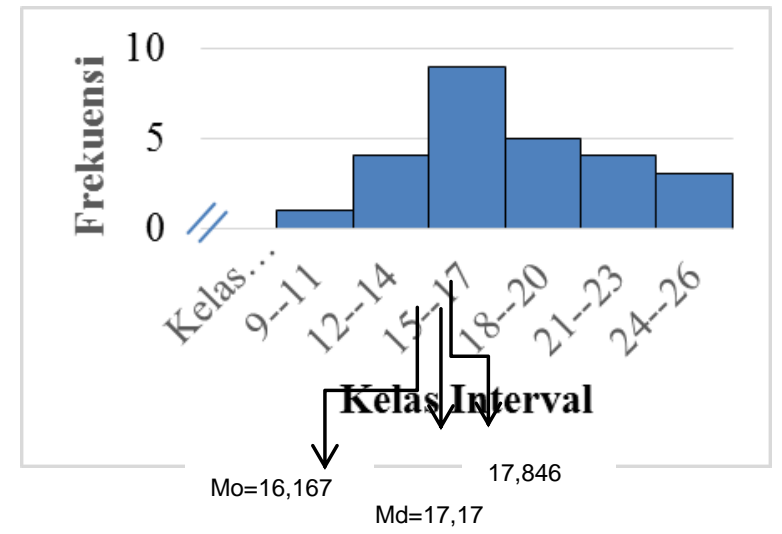

Gambar 2. Histogram Hasil Belajar IPA Kelompok Kontrol

Dengan demikian, hasil belajar IPA pada kelompok eksperimen lebih baik dibandingkan dengan hasil belajar kelompok kontrol. Setelah melakukan analisi statsistik deskriptif, selanjutnya dilakukan uji prasyarat untuk menguji hipotesis. Uji prayarat yang dilakukan adalah uji normalitas dan homogenitas. Uji normalitas data dilakukan terhadap data hasil belajar IPA kelompok ekperimen dan kelompok kontrol. Berdasarkan analisis data yang dilakukan, dapat disajikan hasil uji normalitas sebaran data hasil belajar IPA kelompok eksperimen dan kelompok kontrol pada Tabel 3 dibawah ini

Tabel 3. Hasil Uji Normalitas Sebaran Data Hasil Belajar IPA

\begin{tabular}{|c|c|c|c|c|}
\hline No & $\begin{array}{l}\text { Kelompok Data Hasil } \\
\text { Belajar }\end{array}$ & $\chi^{2}$ & $\begin{array}{l}\text { Nilai Kritis dengan Taraf } \\
\text { Signifikan } 5 \%\end{array}$ & Status \\
\hline 1 & Eksperimen & 4,08 & 7,815 & Norma \\
\hline 2 & Kontrol & 2,38 & 7,815 & Normal \\
\hline
\end{tabular}

Berdasarkan hasil perhitungan dengan menggunakan rumus Chi-Kuadrat $\left(X^{2}\right)$ diperoleh harga $X^{2}$ hitung hasil belajar IPA kelompok ekperimen sebesar 4,08 dan $X^{2}$ tabel dengan derajat kebebasan (dk) = 3 pada taraf signifikan $5 \%$ adalah 7,815 . Hal ini berarti $X^{2}$ hitung hasil belajar IPA kelas ekperimen lebih kecil dari $X^{2}$ tabel $(4,08<7,8147)$ sehingga data hasil belajar IPA kelompok ekperimen berdistribusi normal. Sedangkan $X^{2}$ hitung hasil belajar IPA kelompok kontrol sebesar 2,38 dan $X^{2}$ tabel dengan derajat kebebasan $(\mathrm{dk})=3$ pada taraf signifikan $5 \%$ adalah 7,815 . Hal ini berarti $X^{2}$ hitung hasil belajar IPA 
kelompok kontrol lebih kecil dari $X^{2}$ tabel $\left.2,38<7,815\right)$ sehingga data hasil belajar IPA kelompok kontrol berdistribusi normal.

Selanjutnya, uji homogenitas dilakukan terhadap varians pasangan antara kelompok eksperimen dan kelompok kontrol. Hasil uji homogenitas varians antara kelompok eksperimen dan kelompok kontrol disajikan pada Tabel 4 dibawah ini.

Tabel 4. Hasil Uji Homogenitas Kelompok Eksperimen dan Kontrol

\begin{tabular}{ccccc}
\hline Sumber Data & Varians & $\mathrm{F}_{\text {hitung }}$ & $\begin{array}{c}\mathrm{F}_{\text {tabel }} \text { dengan Taraf } \\
\text { Signifikan 5\% }\end{array}$ & Status \\
\hline Kelompok Ekperimen & 18,360 & 1,029 & 1,984 & Homogen \\
Kelompok Kontrol & 17,835 & & & \\
\hline
\end{tabular}

Berdasarkan tabel di atas, diketahui bahwa $F_{\text {hitung }}$ sebesar 1,029 , sedangkan $F_{\text {tabel }}$ dengan d $b_{\text {pembilang }}$ $=22$ dan $\mathrm{db}_{\text {penyebut }}=25$, pada taraf signifikan $5 \%$ adalah 1,984. Hal ini berarti $F_{\text {hitung }}$ lebih kecil dari $F_{\text {tabel, }}$, sehingga dapat dinyatakan bahwa varians data hasil post-test kelompok ekperimen dan kelompok kontrol adalah homogen. Setelah diperoleh hasil dari uji prasyarat analisis data, dilanjutkan dengan pengujian hipotesis penelitian $\left(\mathrm{H}_{1}\right)$ dan hipotesis nol $\left(\mathrm{H}_{0}\right)$. Pengujian hipotesis tersebut dialkukan dengan menggunakan rumus polled varians dengan kriteria $\mathrm{H}_{0}$ ditolak jika $\mathrm{t}_{\text {hitung }}>\mathrm{t}_{\text {tabel }}$ dan $\mathrm{H}_{0}$ diterima jika $\mathrm{t}_{\text {hitung }}<$ $t_{\text {tabel }}$. Rangkuman hasil perhitungan uji-t kelompok eksperimen dan kontrol disajikan pada Tabel 5 dibawah ini

Tabel 5. Rangkuman Hasil Uji-t

\begin{tabular}{c|c|c|c|c|c|c}
\hline Kelompok & $\mathbf{N}$ & $\mathbf{D b}$ & $\mathbf{M e a n}(\bar{x})$ & $\mathbf{s}^{2}$ & $\mathbf{t}_{\text {hitung }}$ & $\mathbf{t}_{\text {tabel }}$ \\
\hline Eksperimen & 23 & 47 & $\begin{array}{l}23,174 \\
17,846\end{array}$ & 17,360 & 4,349 & 2.0117 \\
Kontrol & 26 & &
\end{tabular}

Berdasarkan tabel rangkuman analisi di atas, dapat diketahui $t_{\text {hitung }}=4,349$ dan $t_{\text {tabel }}=2,0117$ untuk $\mathrm{db}=47$ pada taraf signifikansi 5\%. Berdasarkan kriteria pengujian, karena $t_{\text {hitung }}>t_{\text {tabel }}$ maka $\mathrm{H}_{0}$ ditolak dan $\mathrm{H}_{1}$ diterima. Artinya, terdapat pengaruh yang signifikan model pembelajaran make a match berbasis penilaian portofolio pada hasil belajar siswa kelas V SD di Gugus VIII Kecamatan Sawa Kabupaten Buleleng tahun pelajaran 2017/2018.

Berdasarkan deskripsi data hasil penelitian, siswa dengan perlakuan model pembelajaran make a match berbasis penilaian portofolio memiliki hasil belajar IPA yang lebih tinggi dibandingkan dengan siswa yang tidak mendapatkan perlakuan model pembelajaran make a matchberbasis penilaian portofolio. Tinjauan ini didasarkan pada rata-rata skor hasil belajar IPA siswa dan hasil análisis uji-t. Rata-rata skor hasil belajar IPA siswa yang mendapatkan perlakuan model pembelajaran make a match adalah 23,174 lebih besar dari pada rata-rata skor hasil belajar siswa tidak mendapatkan perlakuan dengan model pembelajaran make a match yaitu 17,846. Selanjutnya berdasarkan analisis data menggunakan uji-t, diketahui $t_{\text {hitung }}=4,349$ dan $t_{\text {tabel }}(d b=47$ pada taraf signifikansi $5 \%)=2,0117$. Hasil perhitungan tersebut menunjukkan bahwa $t_{\text {hitung }}$ lebih besar dari $t_{\text {tabel }}\left(t_{\text {hitung }}>t_{\text {tabel }}\right)$. Terdapat pengaruh yang signifikan pada hasil belajar IPA siswa yang mendapatkan perlakuan model pembelajaran make a match berbasis penilaian portofolio disebabkan karena beberapa hal.

Faktor pertama, pada pembelajaran dengan model pembelajaran make a match, siswa ditugaskan untuk mencari pasangan berdasarkan kartu yang dipegang setelah mempelajari konsep. Bagi siswa yang dapat mencari pasangan dari kartu yang dipegang dengan benar sebelum batas waktu yang ditentukan akan diberikan poin. Pembelajaran demikian membuat siswa menjadi aktif dan senang. Kondisi ini membuat siswa mau belajar mandiri dan saling bekerjasama dengan temannya. Hal ini berarti minat belajar siswa menjadi lebih baik. Adanya minat belajar menyebabkan hasil belajar lebih baik. Pendapat ini sejalan dengan pendapat Suyatno (2009), yang menyatakan bahwa model pembelajaran make a match merupakan kegiatan pembelajaran dimana siswa mencari pasangan sambil belajar mengenai suatu konsep atau topik dalam suasana yang menyenangkan. Selanjutnya Nashar (2004), yang menyatakan bahwa minat belajar yang dimiliki oleh anak dalam setiap pembelajaran sangat berperan untuk meningkatkan hasil belajar siswa dalam mata pelajaran tertentu, artinya semakin tinggi minat belajar siswa semakin tinggi pula hasil belajar yang diperoleh. 
Faktor Kedua, pemberian reward berupa bintang dan tepuk tangan untuk siswa yang menemukan pasangan kartu yang dipegang. Membuat anak lebih bersemangat dan meningkatkan motivasi siswa dalam proses pembelajaran. Dengan motivasi belajar siswa yang meningkat, maka hasil belajar siswa pun menjadi optimal. Pendapat ini sejalan dengan pendapat Jaelani (2011), yang menyatakan bahwa adanya motivasi yang baik dalam belajar akan menunjukkan hasil yang baik pula. Dengan adanya usaha yang tekun dan didasari motivasi yang baik, maka siswa dapat mencapai tujuannya dengan hasil belajar yang optimal.

Faktor ketiga, perbedaan haisl belajar yang signifikan antara kelas ekperimen dan kelas kontrol disebabkan karena penggunaan penilaian porotofolio sebagai alat bantu dalam meningkatkan hasil belajar siswa. Penggunaan penilaian ini guru mamapu mengumpulkana karya yang dimiliki anak didik (baik yang tertulis, maupun berbagai penampilan yang tersimpan rapi) yang menggambarkan perkembangan siswa di dalam kelas maupun di luar kelas selama mengikuti proses pembelajaran. Guru dapat melihat perkembangan siswa melalui tugas yang dikerjakan oleh siswa, baik pada awal pengetahuan maupun hasil setelah dilakukannya perbaikan (Alentina,2014) selaian itu guru juga bisa menyajikan wawasan dalam belajarnya: cara berpikirnya, pemahamnnya atas pelajaran yang bersangkutan, kemampuan mengungkapkan gagasan-gagasan, sikap terhadap mata pelajaran yang bersangkutan .

Berbeda halnya pada kelas kontrol dengan model pembelajaran konvensional, yakni guru lebih banyak mendominasi kegiatan pembelajaran. Pada proses pembelajaran, siswa cenderung pasif dan hanya mencatat, menghafal, mengerjakan tugas, dan mendengarkan sesuai dengan perintah guru tanpa berupaya menemukan sendiri konsep-konsep yang dipelajari. Dalam kegiatan pembelajara. Guru masih berusaha memindahkan pengetahuan yang dimilikinya kepada siswa. Kegiatan ini menyebabkan siswa kurang mampu dalam mengaplikasikan konsep yang dipelajarinya dalam kehidupan sehari-hari karena pengetahuan awal yang dimilikinya tidak diperhatikan seperti potensi-potensi siswa. Temuan ini sejalan dengan pendapat Santayasa (2005) bhawa pembelajaran konvensional merupakan model pembelajaran yang menekankan penyampaian materi dari guru kepada siswa. Sama halnya dengan penelitian ini, dalam kegiatan pembelajaran siswa cenderung pasif, siswa lebih banyak mendengarkan, mencatat, mengerjakan tugas yang diberikan oleh guru. Hal ini menyebabkan siswa tidak diberikan kesempatan untuk mengembangkan potensi-potensi yang ada dalam diri siswa serta kurang diperhatikannya pendapat siswa.

Berdasarkan uraian tersebut, terlihat bahwa model make a match berbasis penilaian portofolio lebih lebih unggul dibadingkan dengan model pembelajaran konvensional. Temuan penelitian menunjukkan bahwa model pembelajaran make a match berbasis penilaian portofolio berpengaruh positif terhadap hasil belajar IPA siswa dengan kecendrungan sebagain besar memperoleh nilai tinggi

Keberhasilan ini didukung oleh keberhasilan penelitian yang dilakukan oleh Atini (2013), dengan judul "Penerapan Model Pembelajaran Make A Match Berbasis Budaya Lokal Bali untuk Meningkatkan Hasil Belajar IPA Siswa Kelas V SD N 2 Cempaga pada semester 1 Tahun Pelajaran 2013/2014". Berdasarkan hasil penelitian yang telah dilakukannya, setelah menerapkan model make a match, hasil belajar IPA pada siswa kelas V SD N 2 Cempaga mengalami peningkatan. Sebelum diberikan tindakan penelitian, rata-rata hasil belajar siswa hanya sebesar 45,5. Pada siklus I, rata-rata hasil belajar IPA siswa menjadi sebesar 60,5, dan pada siklus II meningkat menjadi 82,5. Hasil penelitian ini juga diperkuat oleh Suandayani (2012), dengan judul "Pengaruh Model Pembelajaran Make A Match berbasis Media Lingkungan Terhadap Hasil Belajar IPA Siswa Kelas IV Sekolah Dasar Gugus II Kecamatan Kuta Utara Tahun Pelajaran 2012/2013". Berdasarkan hasil penelitian yang telah dilakukannya, setelah menerapkan model make a match, hasil belajar IPA pada siswa kelas IV Sekolah Dasar Gugus II Kecamatan Kuta Utara mengalami peningkatan. Hasil penelitiannya menunjukkan bahwa terdapat perbedaan hasil belajar IPA antara siswa yang mengikuti pembelajaran dengan model pembelajaran Make A Match dan Media lingkungan dan siswa yang mengikuti pembelajaran konvensional. Rata-rata hasil belajar kelas eksperimen lebih tinggi daripada kelas kontrol, yakni 24,7 untuk kelas ekperimen dan 19,3 untuk kelas kontrol.

Dengan demikian hasil belajar siswa yang mendapatkan perlakuan model pembelajaran make a match lebih tinggi dibandingkan siswa yang tidak mendapatkan perlakuan model pembelajaran make a match pada mata pelajaran IPA kelas V di Gugus VIII, Kecamatan Sawan, Kabupaten Buleleng tahun pelajaran 2017/2018. Hal ini disebabkan karena model pembelajaran make a match menuntut siswa agar mampu memahami suatu materi dengan menggunakan kartu pasangan. Selain itu, model pembelajaran make a match ini menuntut setiap siswa aktif dan cekatan untuk mencari pasangan kartu yang dipegang. Hal ini membuat pembelajaran menjadi lebih menyenangkan sehingga dapat meningkatkan hasil belajar siswa. 


\section{Simpulan Dan Saran}

Berdasarkan rumusan masalah dan pembahasan di atas, dapat disimpulkan bahwa terdapat pengaruh yang signifikan hasil belajar IPA antara kelompok siswa yang dibelajarkan menggunakan model pembelajaran make a match berbasis penilaian portofolio dan kelompok yang dibelajarkan dengan pembelajaran konvensional pada siswa kelas V SD Di Gugus VIII Kecamatan Sawan, Kabupaten Buleleng Tahun Pelajaran 2017/2018. Berdasarkan hasil uji-t, diperoleh bahwa $t_{\text {hitung }}$ adalah 4,34 sedangkan $t_{\text {tabel }}$ pada taraf signifikan 5\% dan db 47 adalah 2,0117. Disamping itu, rata-rata skor hasil belajar ipa kelompok siswa yang dibelajarkan dengan model make a match berbasis penilaian portofolio $(23,174)$ lebih tinggi dari pada rata-rata skor kelompok siswa yang dibelajarkan dengan pembelajaran konvensional $(17,846)$. Dengan demikian, model Make a Match berbasis penilaian portofolio berpengaruh terhadap hasil belajar IPA pada siswa kelas V SD Semester Genap di Gugus VIII, Kecamatan Sawan, kabupaten Buelelngtahun pelajaran 2017/2018.

Saran-saran yang dapat disampaikan berdasarkan penelitian yang telah dialkukan adalah 1) Disarankan kepada siswa untuk selalu bertindak aktif dan kreatif dalam proses kegiatan belajar, sehingga belajar akan menjadi lebih bermakna dan hasil belajar yang maksimal dengan mudah dapat dicapai. 2) Disarankan kepada guru di sekolah untuk menggunakan atau menerapkan model pembelajaran Make a Match Berbasis Penilaian Portofolio dalam setiap proses kegiatan mengajar baik khususnya mata peajaran IPA dan pada mata pelajaran lain pada umunya di Sekolah Dasar. Saran ini diajukan mengingat hasil daripada penelitian ini menunjukkan bahwa model pembelajaran Make a Match Berbasis Penilaian Porotofolio dapat meningkatkan hasil belajar IPA. 3) Disarankan kepada Kepala Sekolah agar memberi kesempatan kepada guru-guru untuk menerapkan model-model pembelajaran yang inovatif salah satunya model pembelajaran make a match berbasis portofolio serta menyediakan media ataupun alat-alat yang mendukung proses pembelajaran dikelas untuk meningkatkan hasil belajar 4) Disarankan kepada peneliti lain yang berminat untuk menggunakan penelitianan ini sebagai salah satu acuan kepustakaan untuk melakukan penelitian baik pada variabel yang sama maupun variabel yang berbeda.

\section{Daftar Rujukan}

Agung, A.A. Gede.2014. Buku Ajar Metodologi Penelitian Pendidikan. Edisi 2. Cetakan Pertama. Singaraja: Aditya Media Publising.

Alentina, Ni. Pt. 2014. "Model Pembelajaran Sinektik Berbasis Penilaian Portofolio Berpengaruh Terhadap Hasil Belajar IPS Siswa Kelas V SD Gugus Letkol Wisnu Denpasar Utara". Mimbar Pgsd. Vol 2, No 3 Tersedia pada https://ejournal.undiksha.ac.id (diakses pada 8 Februari 2018).

BNSP. 2006. Panduan Penyusunan kurikulum Tingkat Satuan Pendidikan Jenjang Pendidikan.

Jaelani.2011. Teori Motivasi Belajar. Jakarta: Rajawali Press.

Muliyantini, P., \& Parmiti, D. P. 2017. "Penerapan Model Pembelajaran Group Investigation (Gi) Untuk Meningkatkan Hasil Belajar IPA Kelas V". Jurnal Ilmiah Sekolah Dasar, Vol 1. No 2 Tersedia pada. https://ejournal.undiksha.ac.id/index. (Diakses pada tanggal 12 Maret 2018).

Nashar. Drs. 2004. Peranan Motivasi dan Kemampuan Awal dalam Kegiatan Pembelajaran. Jakarta : Delia Press.

Samatowa, Usman. 2010. Pembelajaran IPA Di Sekolah Dasar. Jakarta: PT Indeks.

Santayasa, I Wayan. 2005. Belajar dan Pembelajaran. Singaraja: Institusi Keguruan Dan Ilmu Pendidikan.

Sisdiknas. 2006. Undang-Undang Republik Indonesia Nomor 20 Tahun 2003 SISDIKNAS Sistem Pendidikan Nasional. Bandung: Fokusmedia.

Shoimin, Aris. 2014. 68 Model Pembelajaran Inovatif dalam Kurikulum 2013. Jakarta: AR-RUZZ Media.

Susanto, Ahmad. 2013. Teori Belajar dan Pembelajaran di Sekolah Dasar. Jakarta: Kencana Prenada Media Group. 
Suyatno. 2009. Menjelajah Pembelajaran Inovatif. Sidoarjo:Masmedia Buana Pustaka.

Trianto. 2009. Mendesain Model Pembelajaran Inovatif-Progresif. Jakarta: Kencana Prenada Media Group.

Yesiana, P. F. 2016." Pengaruh Model Pembelajaran Make A Match Terhadap Hasil Belajar IPA Siswa Kelas V SD Negeri Gugus IV Kabupaten Buleleng Tahun Pelajaran 2016/2017". Mimbar Pgsd. Volume 6, Nomor 3. Tersedia pada ttps://ejournal.undiksha.ac.id/index.php/JJPGSD/article. (diakese pada tanggal 20 Februari 2018). 